\title{
Evaluation of Kkbpk Program through Implementation of Family Planning Village as A Community Empowerment Efforts in South Sulai Sulai District, 2018
}

\author{
Rusnawati", Taufik Hidayat, Agung Nugroho \\ Master of Science Development Administration, Lambung Mangkurat University, Indonesia
}

DOI: $10.36348 /$ sjef.2019.v03i11.006

| Received: 09.11.2019 | Accepted: 15.11.2019 | Published: 19.11.2019

*Corresponding author: Rusnawati

\section{Abstract}

One concrete form in human development is through the Establishment of the Family Planning Village (Kampung KB). The KB Village Program is a government program in the Nawacita development priority agenda as part of strengthening the KKBPK program. The research approach used by researchers is descriptive qualitative, with the Context, Input, Process, Product (CIPP) Evaluation model. The results of the study are that the success of the KB villages is largely determined by the active role of the community at various levels, the need for program intervention, funding, facilities, infrastructure, IEC, advocacy and mobilization of SKPD and across sectors with the ultimate target of a collective and sustainable cultural movement, then the KB Village can be considered as a community initiative itself is not merely a government program. The role of the Bupati is very important with the District KB Village Working Group Team by involving members of the DPRD sitting together to arrange an intervention program in the KB Village as well as to maintain the sustainability of the program. In addition, assistance is also needed in the implementation of the KKBPK program in the field and skills training for UPPKS and other Poktan groups as well as providing APBD funds in support of advocacy, IEC and mobilization in the Kampung KB area.

Keywords: Family planning, human development, district government.

Copyright @ 2019: This is an open-access article distributed under the terms of the Creative Commons Attribution license which permits unrestricted use, distribution, and reproduction in any medium for non-commercial use (NonCommercial, or CC-BY-NC) provided the original author and source are credited.

\section{INTRODUCTION}

The implementation of Kampung KB requires the support of all government agencies and even more private parties to work in accordance with the needs and conditions of the local area, and is carried out at the lowest level of government [1]. The KB village program is one of the government's realization to improve the quality of life of the community in accordance with the indicators of the achievement of the Family Planning and Family Development (KKBPK) program. The success of the Family Planning and Family Development (KKBPK) program can be seen from 3 aspects: first, from the aspect of controlling population quantity, second, from the aspect of improving the quality of the population which in this case is measured by increasing the resilience and welfare of the family.

Increasing family resilience and welfare can be traced through sharing indicators that reflect the implementation of 8 family functions as stated in Government Regulation No. 87 of 2014 concerning Development of Population and Family Development,
Family Planning and Family Information Systems. In the Government Regulation mentioned that 8 family functions include: (1) religious function, (2) sociocultural function, (3) love function, (4) protection function, (5) reproductive function, (6) socialization and education function, (7) economic functions and (8) environmental development functions. The indicator is then manifested in various achievements as measured by an increase in the number of new family planning, serving health of pregnant and lactating women, active adolescents in the activities of Youth Family Development (BKR) and the Center for Information and Adolescent Reproductive Health Counseling (PIK$\mathrm{R}$ ), illiterate women, increasing participation of underprivileged and KS-1 families in Efforts to Increase Family Welfare Income (UPPKS) [1].

Determination of $\mathrm{KB}$ Village is certainly inseparable from the criteria that have been made by the BKKBN, [8] at least there are several criteria to determine whether an area is suitable for $\mathrm{KB}$ Village, among others; The number of Pre-Prosperous Families and KS 1 (poor) is above the average of Pre-Prosperous 
and KS 1 at the village / kelurahan level where the village is located. And the number of $\mathrm{KB}$ participants is below the average achievement of $\mathrm{KB}$ participants at the village / kelurahan level where the village is located. Whereas the criteria for the area in the formation of the KB Village include 10 regional categories (one selected), namely: 1) Slums, 2) Coastal or Fishermen, 3) Watershed (DAS), 4) Railroad, 5) Poor Areas (including Urban Poor), 6) Remote, 7) Borders, 8) Industrial Estates, 9) Tourist Areas, and 10) Populous Density. Specific criteria for the establishment of the KB Village include Data criteria, where each RT / RW has Family Data and Maps sourced from the results of Family Data Collection, population data and / or accurate civil disability, as well as population criteria, where the participation rate of school-age population is low, KB Kampung is built located at the RW or hamlet level by using the cultural approach of each region with the main objective to improve the quality of life of the community at the village level or equivalent through population programs, family planning and family development, sector development in order to realize quality small families and increase the number of participants KB active MKJP [2].

In South Kalimantan Province, the number of $\mathrm{KB}$ villages declared as of December 2018 is $141 \mathrm{~KB}$ villages, spread over 11 regencies, while for $\mathrm{Hulu}$ Sungai Selatan Regency as of December 2018 the number of $\mathrm{KB}$ villages declared by the Regent of Hulu Sungai Selatan is as many as $22 \mathrm{~KB}$ villages spread in 11 Districts, 144 Villages and 4 Kelurahan. Demographically, the KB Village that has been launched by the Regent of Hulu Sungai Selatan is spread over swamps, mountains and land. General Data on Population Profiles, Family Planning in the Population Control Office, Family Planning for Women's Empowerment and Child Protection in Hulu Sungai Selatan Regency as of December 2018 are as follows:

Table-1: General Data from DPPKBPPPA 2018

\begin{tabular}{|l|l|c|}
\hline No. & Description & Amount available \\
\hline 1 & districts & 11 \\
\hline 2 & PPLKB/District KB Officer & 0 \\
\hline 3 & Village/Village & 148 \\
\hline 4 & PKB/PLKB & 23 \\
\hline 5 & PPKBD & 148 \\
\hline 6 & PPKBD Sub & 586 \\
\hline 7 & KB group & 148 \\
\hline 8 & BKB Activity Group & 154 \\
\hline 9 & BKR Activity Group & 34 \\
\hline 10 & BKL group & 37 \\
\hline & UPPKS Activity Group & 41 \\
\hline & Number of PIK R/M & 38 \\
\hline
\end{tabular}

The above data in terms of quantity of field line officers, especially PKB, are not yet proportional to the population and villages in Hulu Sungai Selatan District, ideally $1 \mathrm{PKB}$ is in charge of 1-2 villages, while in Hulu Sungai Selatan District 1 PKB can be in charge of 5-8 villages, Hulu Sungai Selatan Regency still needs as many as 50 PKBs so that PKB can work optimally in fostering its village. With the low quantity of the existing number of PKB, automatically the formation of family resilience groups cannot run optimally, Activity Groups such as BKB, BKR, BKL and UPPKS need to be re-formed, in order to add and optimize existing activity groups. According to the researchers' point of view, both in terms of quality and quality, PKB HR in Hulu Sungai Selatan Regency needs to be increased again, due to the low achievements of the KB program in 2018, in order to oversee and assist KKBPK programs in the field lines the following year in order to become better.

KB Village As a new program, according to Rochyati, each policy must be evaluated so that the success or failure of a policy product will be known, so that normatively a recommendation will be obtained whether the policy can be continued, needs improvement before continued or dismissed. In addition, the purpose of the evaluation is to assess the relationship between policies and their implementation, in the form of policy impacts, whether the impacts are in accordance with the estimates or not. From the results of the evaluation it can be assessed whether a policy or program provides benefits to the intended community.

The results of the pre-field study in December 2018, taking into account and considering the geographical situation of the village, population density, level of education and achievement targets, the locus of research were three villages spread in 3 subdistricts with geographical swamps, mountains and land, namely KB village Parigi village South Daha, Malinau Village, Loksado District and Bariang Village, Kandangan District. Through the results of this pre-field study, researchers are interested in evaluating the KKBPK Program through the Implementation of the KB Village in Hulu Sungai Selatan District in 2018 based on the Context, Input, Process and Product indicators. 


\section{METHODS}

This research is an evaluation research using a quantitative descriptive approach and a CIPP (Context, Input, Process, and Product) evaluation model developed by Stufflebeam. This model was chosen because it is a very appropriate evaluation model to evaluate the effectiveness of the implementation of a program, including program evaluation [3]. Research Subjects Research subjects in this study include: Head of the Population Control Office, Family Planning, Women's Empowerment and Child Protection in the Upper South Sungai Regency, working groups in KB Village in Bariang Village, Head of Parigi Village in Daha Selatan District, South Daha Sub-District, PUS in Malinau Village Loksado District. Data Analysis Techniques Research data obtained from the evaluation of each research variable based on research indicators compiled into research instruments $[4,5]$. To determine the research data, evaluation criteria are needed for each instrument. The criteria are based on empirical criteria, namely criteria developed in the field with quantitative and qualitative criteria. Each type of criteria with consideration and without consideration. Both remain scientific because they are arranged based on correct reasoning [6].

\section{RESULTS AND DISCUSSION}

According to the Dictionary of Population and Family Planning Terms published by the Directorate of Information and Documentation Technology (Dittifdok) in 2011, "KB Village is one of the efforts to strengthen the KKBPK Program which is managed and organized from, by, and for the community in empowering and facilitating the community to obtain services. Total family planning program, as an effort to create a quality family".

$\mathrm{KB}$ Village is a regional unit at the level of $\mathrm{RW}$, hamlet or equivalent, which has certain criteria, where there is integration of population programs, family planning, family development and related sector development carried out systematically and systematically. According to Notoatmodjo, Kampung $\mathrm{KB}$ is an effort to strengthen the KKBPK program that is managed and organized for the community in empowering and providing facilities to the community to obtain total $\mathrm{KB}$ program services, as an effort to create quality families.

$\mathrm{KB}$ Village has become a strategic innovative program in manifesting the KKBPK program in the most complete field. Because the KB Village became a model or miniature of development involving all sectors in the community. The presence of KB Village aims to improve the quality of life of the community at the village level or equivalent through the KKBPK program and the development of other sectors in order to create quality small families. In principle the KKBPK program realizes a happy, prosperous small family by carrying out eight family functions. The application of this family function helps families be happier and more prosperous, free from poverty, ignorance and backwardness. Explanation of the results of the study, that the evaluation of how the KKBPK Program evaluation through the Implementation of the $\mathrm{KB}$ Village Program in the Hulu Sungai Selatan District uses an evaluation of the CIPP model that is context, input, process and product. The following is a discussion of the results of research on the implementation of the KB Village program in Hulu Sungai Selatan Regency.

\section{Context Evaluation (C)}

Evaluation of the context of program implementation presents data about the reasons for setting program goals and priorities [7]. The results of the context evaluation research were obtained by looking at the identity of the family planning village in the Hulu Sungai Selatan Regency that already had clear legality. Sources of Policy Reference and Implementation for the Development of KB Villages in the Central BKKBN are referring to the Minister of Home Affairs Circular Letter No.440 / 70 / SJ dated January 11, 2016, Regarding the Declaration and Establishment of KB Villages throughout Indonesia; Circular of the Head of the Central BKKBN No.046 / BL / 200 / B4 / 2016 dated January 12, 2016, concerning the live broadcast of the declaration of $\mathrm{KB}$ villages throughout Indonesia [9].

Whereas in the Hulu Sungai Selatan Regency as the Reference Source is the Decree of the Hulu Sungai Selatan Regent 188.45 / 434 / KUM / 2017 Regarding the Establishment of the KB Village in each Sub-District in the South Hulu Sungai Regency. As a follow up and Commitment of Regional Heads in the success of the KKBPK Program at the bottom line through the Implementation of the KB Village Program. The $3 \mathrm{~KB}$ villages in the Hulu Sungai Selatan Regency do not yet have their own vision and mission, but are referred to the BKKBN (National Population and Family Planning Agency) vision and mission. The implementation of the program of activities remains continuous or in line with the vision and mission of the BKKBN [10-12].

In implementing the implementation, the Juknis KB Village is also very necessary, because with the existence of a standard, namely the Juklak (Implementation Manual), it is expected that the activities in the KB Village program will run well and smoothly. The target of the KB Village program in the Hulu Sungai Selatan Regency is through 3 comparison of the KB Village, adjusted to the type of program implemented. Examples of program activities are UPPKS activities that target people who want to 
improve the economy and creativity such as housewives, BKB activities targeting toddlers, targeted BKR Adolescents and parents who have teenagers, and BKL targets the elderly.

\section{Input Evaluation (I)}

Input evaluation provides data to determine how the use of resources that can be used to achieve program objectives [7]. Resources that include funds or various incentives that can facilitate the effectiveness of implementation. Resources in the implementation of the $\mathrm{KB}$ village program have a very important influence. From human resources, to implement the Kampung KB programs are quite good and received a positive response from the community.

The source of funds for the KB Village comes from the APBN / APBD / Village Fund / cross-sector budget support, based on the amount of funds spent. From the 3rd comparison of the KB Village in the South Hulu Sungai Regency, the income of the fund besides coming from government assistance, also has its own income through cash, because the funds provided by the government are only for certain activities, whereas in KB Village many activities are carried out both fixed activities or even activities that are continuous, therefore the management of the $\mathrm{KB}$ Village initiates to hold cash funds, in addition to the implementation of activities, also as a reserve fund / savings of the KB Village.

The Population Data House was basically formed to improve data governance, especially in the village or village. The existence of data in the House Population Data is integrated with other data sources, such as sectoral data collected by various institutions, for example data on agricultural land, plantations, family latrine ownership data, underfives malnourished or identified stunting data, population data according to education level, occupation and others, all of which can be used for development interventions. Data quality is expected to be better, because the data is collected from the community, by the community and for the community in order to improve the welfare of the community itself.

The Population Data House can be used as a model of a healthy home, a smart home, a reading house, an eco-friendly house, a child-friendly house and a population-minded home. Technically, the Population Data House is managed by the Population Data House Administrator which consists of the Chairperson, Deputy Chairperson, Data Collection and Update Section, Data Analysis Section, Data Services and Utilization Section and Data Operational Section. The section inaugurated by the Decree of the Head of the Village / Lurah has duties and responsibilities including inventorying population data and data needed by the community collected from, by and for the community. Also identify sources of population data both primary and secondary data in collaboration with KB Field Officers, Health Workers, Agricultural Extension Workers and other sectoral personnel who work in the village. Other duties and responsibilities are collecting primary and secondary data, updating the data collected with the latest conditions, and recording data into a computer or transferring it to a data book, according to prepared tables. After that, do simple processing and analysis and present data in the form of family maps, graphs and tables according to needs and based on available data.

\section{Process Evaluation}

A number of empowerments through groups to obtain services from various fields, such as health, family economy, population, family planning and family planning, as well as other sectors to realize the formation of quality small families are the main conditions for the establishment of the KB Village.

\section{Toddler Family Development (BKB)}

This group is an effort to increase the knowledge, skills and awareness of mothers and other family members in fostering the growth and development of infants. Various activities are carried out through physical, motor, intelligence, social, emotional, and moral stimuli that take place in the process of interaction between mothers or other family members with toddlers.

\section{Youth Family Development (BKR)}

This is a strategic program where efforts are made to prepare quality human resources in the community. The BKR program includes efforts to improve the knowledge, attitudes and skills of parents and other family members in fostering balanced child and adolescent development through effective communication between parents and adolescents, both physically, intellectually, reproductive health, mental emotional, social and moral spiritual.

\section{Elderly Family Development (BKL)}

Not only focusing on toddlers and teenagers. The elderly also need to be fostered through the Elderly Family Development. This is a group in which a series of activities are carried out to increase the knowledge and skills of elderly families in caring for, caring for and empowering the elderly so that their well-being is improved. The purpose of this BKL is to realize the welfare of elderly people who are devoted to God Almighty, independent, productive and beneficial.

\section{Business Group Increased Welfare Family Income (UPPKS)}

This group is a productive economic endeavor with members of a group of family members who interact and consists of various segments, such as the Prosperous Family, both EFAs who have family planning or not. This group aims to form a type of joint venture. Meanwhile in the $\mathrm{KB}$ Village there was 
already DAK support. However, it is not enough, only one KB Village per District, but in this case it puts forward the principle of implementing activities that are effective, efficient, timely and appropriate. The quality of interorganization relations also largely determines the success of achieving the objectives of policy implementation. Effective implementation occurs when the implementers already know what they are doing.

Knowledge and understanding of Parigi Village community policy objectives is quite good. This is shown by the results of research showing that the community, especially cadres of the program can answer when asked about the purpose of this $\mathrm{KB}$ Village. While the knowledge and understanding of the content of the KB Village policy in the community itself is still lacking. This is shown by the fact that some people don't know about the contents of the BKR program. Besides the lack of socialization from the Office of PPKBPPPA regarding the content of the KB Village program and the partial implementation of the KB Village program in the community. While the knowledge and understanding of the contents and policy objectives of the PLKB itself are quite good. This is demonstrated by the implementation of the KB Village program by PLKB based on technical guidelines.

The attitude of the people of Desa Parigi on the policy of the KB Village program is that they are very enthusiastic. Generally, the Parigi Village community participated in the KB Village program. Whereas the attitude of the PKB held by the KB Village Program on the policy of this program has been classified as good because based on the results of the study, PKB officials in Parigi Village are always ready and responsive to serving the community to participate in the KB Village program. Overall, the intensity of the attitude of the community and PKB employees towards this program was high. This is because; based on the results of the study, from the beginning the program was launched until now the attitude of the program implementers is equally good.

New breakthroughs can be realized in the form of creativity and innovation. Only people who are tough, steadfast in dealing with situations, persistent, confident and resistant to trials and challenges are able to create creativity and innovation. Schedule of activities in 3 comparisons of the $\mathrm{KB}$ villages in the South Hulu Sungai Kabuaten, namely: Schedule for the implementation of the UPPKS program in the KB village Parigi Village every second week of every month, while BKB, BKR and BKL every third and fourth week of each month. The implementation schedule of the UPPKS program in KB Village Malinau Village the 3rd week of each month, while the BKB every 2 nd week adjusts to the posyandu, BKR and BKL schedules every 4th week each month. UPPKS program implementation schedule in KB Village Bariang Village week 4, BKB and BKR week 2 every month, BKL week 3 every month.

\section{Product Evaluation $(\mathbf{P})$}

The results of the program activities are outputs obtained by the community while carrying out activities in the KB Village Program. Achievement of the KB Village Program needs to be reviewed from the achievements that have been obtained, in general the KB Village in the Hulu Sungai Selatan Regency has never participated in a competition, either between KB Village, district / city level, until the provincial level. However, the Parigi village KB village became the Pilot Village in the Upper South Sungai Regency. KB Parigi village has participated in the provincial level PIK Youth competition and won second place,

Community satisfaction becomes an evaluation whether during implementation has met the standard implementation of activities or not. It was found from the results of interviews that the community was satisfied with the implementation of the KB Village program. Thus, community satisfaction is one of the benchmarks that can show support for the KB Village Program located in the Hulu Sungai Selatan Regency.

Community satisfaction is also related to the impact of the $\mathrm{KB}$ Village program which provides a change in attitude, ability, and knowledge to the community. Communities that tend to be individualistic, with the existence of the KB Village, become mingled with each other, cooperate with each other, establish friendships, and communicate. The actual family planning program has been around for a long time, but because of issues that are believed by the community it has hampered this. Most of the people in Parigi Village are Muslim. Most of the people think that the Family Planning Program or someone who participates in the Family Planning program is doing wrong or doing something that is forbidden by their religion (Islam). In addition, there is also a mindset that more and more children will add a lot of fortune, where the mindset is an old pattern of thinking that is no longer appropriate when used. Advocacy and IEC in the village need to educate about the $\mathrm{KB}$ Village socialization. One of the important elements in conducting socialization is the process of socialization which means the ways in which culture (beliefs, traditions, lifestyles, languages, moral life rules and variations in skills) are shared or needed. As it is known that the existing community has a very strong belief in the issues that exist in the religion they believe in, as well as the old mindset that they implemented in their lives.

This is what underlies the need for education about KB Village socialization in villages. Advocacy and IEC in South Hulu Sungai Regency have done their job, namely by compiling a communication strategy which is then disseminated to the community through 
the KB Village Program. From the stages carried out, the chosen strategy was adjusted to their target, namely the Family, by approaching the South Hulu Sungai District Government, related agencies, community leaders, and religious shops.

Achievement of this effective communication strategy, the strategy carried out by the Advocacy and IEC of the PPKBPPPA Office of Hulu Sungai Selatan Regency also relies on the power of word of mouth which is very effective when practiced in the regions. According to the observations of researchers also, overall Advocacy and IEC have managed to package the message to be conveyed to the public. Evidenced by the persistence of the KB Village program that is still implemented today, and there are plans to implement other KB Village Programs in other suburbs in order to improve the organizational structure so that the people in it are people who have insight and experience regarding family planning. This is done to ensure continuity between the capacity of the people in charge and the program to be carried out.

The researcher also hopes that the Hulu Sungai Selatan District Advocacy and IEC can continue to maintain the KB Village Program, because keeping in mind that these marginal communities need continuous education and motivation. Community participation in activities is generally very good, especially activities that are beneficial and positive, not only activities that are in the KB Village, but what activities are carried out within the community, the activities help the community and are useful for the community, the participation provided by the community is also good. Because $\mathrm{KB}$ Village is a positive program of activities, the people in $3 \mathrm{~KB}$ villages in Hulu Sungai Selatan Regency are quite enthusiastic and participate in participating in the $\mathrm{KB}$ village program activities.

Family Planning and Family Development programs are very good for the community, efforts to build families, improve the quality of the family, by starting to plan the number and program of children. Generally $\mathrm{KB}$ to facilitate parents. The practical thinking of two children is sufficient, in terms of its economy it is also easier for the community, with the synergy of all family planning partners increasing so that the realization of the family planning program will be better, which also affects regional development. Hope in the future all the existing stakeholders, one thought one vision, one mission. In addition, the role of religious and traditional leaders is also very important in the success of the family planning program. Religious leaders and traditional leaders must also join hands in implementing the KB Village program.

TFR can be placed as an indicator of the achievement of population control, but it can also be framed in creating human development. Certainly needed sensitive indicators to assess a policy and the impact that may be caused in the area of population. For this reason, Population Development must provide direction and input regarding sensitive and insensitive policies on population issues. With a well-managed TFR, development investment does not merely focus on infrastructure development and demands land conversion to agriculture, housing or industry. Development investment is more focused on human development and creates conditions for more productive social relations.

This effort was translated into the Family Resilience Program whose paradigm had to be shifted. The family resilience development program is no longer carried out in the context of fostering family planning participation but is far from it. How to create a resilient family so as to give birth to a golden generation for Indonesia in the future, is the challenge of this program. Along with social and economic development, the availability of social protection for the population of Indonesia, including for the Elderly, then slowly the number of children expected is also falling. The family planning service approach must be carried out through the approach of fulfilling reproductive rights. The community considers that family planning is not only because of 'government programs' but because of lifestyle and needs. The challenge going forward is how the state will be present for those who are still very difficult to reach, either physically or socially. Following in general the impact of having a KB Village can be seen in the table below: 


\begin{tabular}{|c|c|c|c|c|}
\hline No & Variable & Description & $\begin{array}{c}\text { Before There was a } \\
\text { Kampung KB }\end{array}$ & After There is a KB Village \\
\hline 1. & Context & $\begin{array}{l}\text { KB program } \\
\text { Purpose } \\
\text { Target } \\
\text { Contraception } \\
\text { Development } \\
\text { Partnership }\end{array}$ & $\begin{array}{l}\text { Suspended } \\
\text { animation/collapse } \\
2 \text { Enough Children } \\
\text { Urban } \\
\text { Simple } \\
\text { Woman } \\
\text { Infrastructure } \\
\text { Egosectoral }\end{array}$ & $\begin{array}{l}\text { Resounding again } \\
\text { Quality Small Family } \\
\text { Poor areas, densely populated, } \\
\text { fishing and remote villages } \\
\text { Modern } \\
\text { Men } \\
\text { Population-oriented development } \\
\text { Global/Multi-sector collaboration }\end{array}$ \\
\hline 2. & Feedback & $\begin{array}{l}\text { HR } \\
\text { Fund } \\
\text { Health insurance } \\
\text { Time } \\
\text { Data } \\
\text { Contraceptive } \\
\text { devices and } \\
\text { drugs (Alokon) }\end{array}$ & $\begin{array}{l}\text { Quantity is not } \\
\text { Proportional } \\
\text { Low quality } \\
\text { State Budget } \\
\text { Jamkesda } \\
\text { General } \\
\text { Unscheduled } \\
\text { Minimal and inaccurate } \\
\\
\text { Limited }\end{array}$ & $\begin{array}{l}\text { Shoulder to shoulder and cooperation } \\
\text { Willingness to increase Knowledge } \\
\text { by following Continuing Education } \\
\text { APBN + APBD } \\
\text { JKN } \\
\text { Increasing the frequency and quality of activities } \\
\text { Rumah Dataku as a data center and } \\
\text { pilot healthy homes, reading houses } \\
\text { smart home, environmentally friendly home } \\
\text { and population oriented } \\
\text { Complete and Modern }\end{array}$ \\
\hline 3. & Process & $\begin{array}{l}\text { Activity } \\
\text { Inter relations } \\
\text { Organization }\end{array}$ & $\begin{array}{l}\text { Not efficient } \\
\text { Do not know what to do } \\
\text { Apathetic } \\
\text { SIGA }\end{array}$ & $\begin{array}{l}\text { Effective, efficient, timely and appropriate } \\
\text { Know what to do } \\
\text { Using the IEC system to individuals, } \\
\text { people and community groups, KIE } \\
\text { done through advocacy efforts and } \\
\text { mobilization, counseling, assistance } \\
\text { and family empowerment } \\
\text { Persuasive, Participatory Society } \\
\text { SIGA Development }\end{array}$ \\
\hline 4. & Product & $\begin{array}{l}\text { Program } \\
\text { Achievement } \\
\text { KB Active } \\
\text { KB MKJP } \\
\text { Unmet Need } \\
\text { EFA has KB } \\
\text { Mindset } \\
\text { Community } \\
\text { Behavior } \\
\text { Appreciation }\end{array}$ & $\begin{array}{l}\qquad \begin{array}{l}70.77 \% \\
12.55 \% \\
10.12 \% \\
76.56 \%\end{array} \\
\text { The KB program only } \\
\text { belongs } \\
\text { government } \\
\text { KB is haraam } \\
\text { Individualist } \\
\text { MKK for Regional } \\
\text { Heads } \\
\text { MKK for PKK Movers } \\
\text { Team Chairperson }\end{array}$ & $\begin{array}{l}\qquad \begin{array}{l}78.77 \% \\
21.23 \% \\
12.52 \% \\
82.30 \%\end{array} \\
\text { Family planning program as a lifestyle and } \\
\text { needs } \\
\text { KB is required for maternal health } \\
\text { Family planning program as a lifestyle and } \\
\text { needs } \\
\text { Changes in attitude, ability and knowledge blend } \\
\text { with each other, cooperate with each other } \\
\text { establish friendship and communicate } \\
\text { Prospective Satya Lancana Development } \\
\text { Recipients } \\
\text { By the President for the Commitment of the } \\
\text { Regional Head towards Population Development }\end{array}$ \\
\hline
\end{tabular}

\section{Achieving the success of the KB Village at least there are $\mathbf{5}$ main factors, including}

Strong commitment from policy makers at all levels (Regency/City, District, and Village). One of the most fundamental things about the success of the KB village is the political will or commitment from the regional head or policy makers at all levels. This commitment must be clear so that each program in the KB Village can work well with budget support. In addition, this commitment is needed to bridge the 
various sectors that must take part in the implementation of the KB Village program. The reason is that the implementation of the $\mathrm{KB}$ Village program is not carried out by the OPD itself in relation to $\mathrm{KB}$, but a synergy of various OPDs is needed.

\section{KKBPK program integration and integration across sectors}

In principle the KKBPK program realizes a happy, prosperous small family by carrying out eight family functions. The application of this family function helps families be happier and more prosperous, free from poverty, ignorance and backwardness. The existence of the KB Village in addition to building a family-based community for the welfare of the community, as well as meeting community needs through the implementation of cross-sectoral integration programs. Cross-sector development and partnerships involve the role of various parties such as the private sector, providers, and other stakeholders. Cross-sector integration in the form of integrated services between sectors that the community needs, such as family planning services, deed making services, building roads and bridges, making ID cards, providing reading books, posyandu, PAUD, P2WKSS and others.

\section{Optimizing facilitation and support of partners/stakeholders}

The success of the KB Village in addition to increasing the role of the government, nongovernmental and private institutions in facilitating, providing assistance and coaching to the community to participate actively in the development program

\section{The enthusiasm and dedication of the KKBPK program managers in the field (PKB, IMP)}

The success of the KB Village Program is important to be supported by increased awareness and community participation in managing the KB Program carried out by the Rural Community Institution (IMP), NGOs, the private sector, community leaders and other relevant government institutions. In an effort to strengthen the program, the IMP together PKB/PLKB always participate in group activities such as family development (BKB, BKR, BKL, PIK-R and UPPKS) as well as other activities at the village level down, such as KB-Health, Education and Information as well as productive economy working group (Pokjanis) in the village, namely at the Village Community Development Institute (LPMD), besides that also with the Village PKK especially in PKK IV working group in charge of $\mathrm{KB}$ and Health issues

\section{Active participation of the community}

Supporting active participation from community leaders, religious and traditional leaders as well as the community in the management and implementation of all activities to be carried out in the $\mathrm{KB}$ village on an ongoing basis is a prerequisite for the formation of a $\mathrm{KB}$ village in order to improve the living standards of all people in their area. In addition, the involvement of the private sector in the development of the Development Program in the KB Village is very important as a form of mutual cooperation from all parties.

\section{CONCLUSION}

KB Village becomes a model or miniature of development involving all sectors in the community. The presence of KB Village aims to improve the quality of life of the community at the village level or equivalent through the KKBPK program and the development of other sectors in order to create quality small families. The KKBPK Program Principle creates a happy, prosperous small family by carrying out eight family functions. The results of the evaluation of the implementation of the $\mathrm{KB}$ village program in Hulu Sungai Regency:

1. Context Evaluation (C) includes policies for the $\mathrm{KB}$ Village that have been supported from the central, provincial, district, sub-district and village levels up to the neighborhood level. Launched through the Decree of the Regent and Village Chief.

2. Input Evaluation (I) regarding the number of PLKB/PKB is still not proportional, but after the existence of this KB Village, all PLKB/PKB work together to succeed the KKBPK program in the area and are assisted by cadres who are so enthusiastic to succeed. Existing sources of funds are still accommodated by the Central Government through the BOKB Funds, While the APBDes funds are still minimal, while for NonGovernmental Funds are still very minimal.

3. Process Evaluation (P) states that there is an increase in the frequency and quality of IEC advocacy activities and mobilization, before there was a KB village PLKB/PKB rarely visited, but after their area was selected as $\mathrm{KB}$ village became a frequent visitor, and formed a new group of activities which were carried out periodically and periodic. And Posyandu services to improve family planning services.

4. Product Evaluation $(\mathrm{P})$ describes that the community is quite satisfied with the implementation of the KB Village Program that makes changes in attitudes, abilities and knowledge. There are changes, both new KB participants, especially KB MKJP and other related programs. However, there is one indicator that has not significantly changed despite the implementation of the KB village. almost 2 years, namely the UPPKS programs have not been maximized in the $3 \mathrm{~KB}$ village locations due to lack of capital for UPPKS, lack of knowledge to create programs and low awareness and community participation in the UPPKS program.

The results of the research in 3 locations of the $\mathrm{KB}$ villages in Hulu Sungai Selatan Regency, namely 
Parigi Village, Daha Selatan District, Malinau Village, Loksado District, and Bariang Village, Kandangan District, concluded that the existence of the $\mathrm{KB}$ village since it was launched in 2017 sufficiently contributed to several indicators of the KKBPK Program. The success of the KKBPK program and other related programs in the KB Kampung area is very much determined by the active role of the community itself at various levels and IEC needs to be the final target, namely a collective and sustainable cultural movement, so that the KB Village can be considered a public initiative not just a Government program. The role of the Bupati is very important with the District KB Village Working Group Team by involving DPRD members sitting together to schedule an intervention program in the KB Village as well as to maintain the sustainability of the program. There is also a need for assistance in the implementation of the KKBPK program in the field and skills training for UPPKS and other Poktan groups as well as providing APBD in support of advocacy, IEC and mobilization in the $\mathrm{KB}$ village area, in order to prepare the country to face the arrival of the 2020 Demographic Bonus.

\section{REFERENCES}

1. BKKBN. (2017). Panduan Pengelolaan Kampung KB. Jakarta.
2. BKKBN. (2015). Petunjuk Tehnis Kampung KB.

3. Arikunto, S. (2002). Manajemen Penelitian. Jakarta: Rineka Cipta.

4. Burhan, B. (2001). Metodologi Penelitian Kualitatif Aktualisasi Metodologis ke Arah: Ragam Varian Kontemporer. Jakarta : Rajawali Pers.

5. Moleong, L. J. (2004). Metodologi Penelitian Kualitatif. Bandung: Remaja. Rosdakarya.

6. Sukandarrumidi. (2002). Metode Penelitian Petunjuk Praktis Untuk Peneliti Pemula. Yogyakarta: Gadjah Mada University Press.

7. Sudjana, D. (2006). Evaluasi Program Pendidikan. Bandung: Rosdakarya.

8. BKKBN. (2018). Panduan Analisis dan Evaluasi Data Program KKBPK Bagi Petugas dan Pengelola Program KKBPK.

9. BKKBN. (2018). Profil Keluarga Indonesia. Jakarta.

10. BKKBN. (2018). Buku Kampung KB Percontohan. Jakarta.

11. BKKBN. (2018). Buku Integrasi Kampung KB Bersama Mitra Kerja. Jakarta.

12. BKKBN. (2018). Panduan dan Monitoring Evaluasi Kampung KB. Jakarta. 